\title{
Effects of Fine Gangue on Strength, Resistivity, and Microscopic Properties of Cemented Coal Gangue Backfill for Coal Mining
}

\author{
Tingye Qi, Guorui Feng, Yanrong Li, Yuxia Guo, Jun Guo, and Yujiang Zhang \\ College of Mineral Engineering, Taiyuan University of Technology, No. 79 Yingze Western Street, Taiyuan, Shanxi 030024, China \\ Correspondence should be addressed to Guorui Feng; fguorui@163.com
}

Received 6 October 2014; Revised 8 March 2015; Accepted 8 March 2015

Academic Editor: Shimin Liu

Copyright (C) 2015 Tingye Qi et al. This is an open access article distributed under the Creative Commons Attribution License, which permits unrestricted use, distribution, and reproduction in any medium, provided the original work is properly cited.

\begin{abstract}
The cemented coal gangue backfill (CGB) in coal mining is normally made of gangue (particle size of 0-15 mm), fly ash, cement, and water. In this study, the effects of the weight content (ranging from $20 \%$ to $60 \%$ ) of fine gangue (0-5 mm) on the microscopic characteristics, resistivity, and compressive strength of CGB were investigated at $3 \mathrm{~d}$ and $28 \mathrm{~d}$ curing times, respectively. The test results indicate that the strengths of the CGB, regardless of the curing time, increased with fine gangue content changing from $20 \%$ up to $40 \%$. Further increase in fine gangue introduced a decrease in the strength. Another observation is that, at 3 days, a general increasing trend of CGB resistivity was noted with fine gangue content. At 28 days, the resistivity of CGB decreased with increase in the fine gangue content. Correlations between the resistivity and compression strength of CGB show a concave pattern, which attribute to the various micromechanism influenced on the resistivity and strength of CGB with different fine gangue content. It indicates that using resistivity to derive strength of CGB is not appropriate.
\end{abstract}

\section{Introduction}

Coal gangue is a solid waste discharged during coal mining and washing processes. The major chemical components of coal gangue are silica $\left(\mathrm{SiO}_{2}\right)$ and alumina $\left(\mathrm{Al}_{2} \mathrm{O}_{3}\right)$, whereas the mineral components are quartz and feldspar [1]. In 2010, the world coal production was $7,273 \mathrm{Mt}$, with a waste yield of $1,455 \mathrm{Mt}$ [2]. In China, coal gangue has accumulated to an amount of approximately $1,000 \mathrm{Mt}$, and the coal gangue discharge increases annually by $100 \mathrm{Mt} / \mathrm{a}$. A vast area of land would be required to process such a large quantity of coal gangue, which would also cause serious environmental problems [3]. In addition, coal mining causes surface subsidence in the mining area. Cemented coal gangue backfill (CGB) produced from gangue is one of the solutions to support the overlying strata when transported to the underground goaf through pipelines $[4,5]$; CGB can reduce landfill area requirements and help solve environmental problems.

CGB used for coal mining backfilling is an engineered mixture of milled gangues ( $75-85 \%$ solids by weight), fly ash, hydraulic binder (3-7\% of total weight of dry paste), and water. Each component of CGB plays a significant role on its short- and long-term performance (i.e., transportation, placement, strength, and stability) $[6,7]$.

Gangue is one of the most important components of CGB for coal mining; this is because crushed gangue exhibits a pozzolanic activity and a certain degree of strength [8-10]. However, considering the slurry transportation restriction and the compressive properties of the CGB, the maximum particle size of coal gangue is normally $15 \mathrm{~mm}$ at maximum. Previous researchers have evaluated the fine gangue (0$5 \mathrm{~mm}$ ) content on the performance of CGB. According to Zheng et al. [10], increasing the fine gangue content may enhance the slump and pumpability of the paste. Fall et al. [11] found that fine tailings are not suitable for CGB because they provide much lower strength than CGB made of coarse tailings. The research on use of $\mathrm{Na}_{2} \mathrm{SO}_{4}$ as chemical activator for paste backfill was also carried out. Besides, the effect of desliming and pozzolans on paste backfill strength has been recently studied $[12,13]$.

The resistivity is an important character of cement matrix. It is related to the microstructure of the matrix (pore structure, porosity, and pore-size distribution). It is also a function of the concentration and mobility of ions in the pore solution 
[14]. In concrete, resistivity was investigated to understand the corrosion resistance and the hydration reaction process $[15,16]$. The change in the content of the raw material for concrete changes its resistivity. For instance, a decrease in the water/cement ratio causes an increase in the resistivity [17]. Adding rice husk ash to the concrete increases its resistivity [18]. An increase in the volume fraction of the aggregate facilitates the formation of current transport at the interface between the aggregate and the slurry, which results in an increase in the resistivity [19]. Compared with concrete, fewer studies focus on the resistivity of CGB.

Several authors have discussed the relationship between resistivity and compressive strength of concrete. Wei et al. [20] made several samples with different cements and measured their resistivity at $24 \mathrm{~h}$, as well as the compressive strength at $28 \mathrm{~d}$. They found that there existed a linear relationship between the two couples of values and concluded that the compressive strength and resistivity mainly depended on the pore structure and micromorphology of products, which were influenced by hydration. Lübeck et al. [21] used White Portland cement, ground granulated blastfurnace slag, and $\mathrm{Na}_{2} \mathrm{SO}_{4}$ to make different samples with three water-to-binder ratios and discovered that the resistivity and compressive strength with the same binder followed a nearly linear relationship owing to the compactness of the structure irrespective of the concrete saturation degree, together with the pore solution conductivity which imposed the influence on the resistivity. Ferreira and Jalali [22] observed a linear relationship between electrical resistivity and compressive strength for the concrete samples prepared by ordinary Portland cement and fly ash cement, because the variation of compressive strength and electrical resistivity depended on the pore structure and the sample geometry change caused by cement hydration. Ramezanianpour et al. [23] prepared 57 concrete mixtures by Portland cement with some supplementary materials including tuff, pumice, rice husk ash, metakaolin, and silica fume. Interestingly, the compressive strength and resistivity of concrete mixtures prepared with different cementitious materials presented no sensible correlation, because the interfacial transition zone (ITZ) only affected the compressive strength but had no obvious influence on the resistivity of concrete, whereas the chemical composition of the pore solution played an important role in resistivity but had little effect on the compressive strength of concrete.

In this study, the effects of fine gangue content on compressive strength, resistivity, and microstructure of CGB at 3 and 28 days curing times were investigated. Attempts were also made to link the strengths of CGB to the resistivity.

\section{Materials and Methods}

\subsection{Materials}

2.1.1. Coal Gangue. The coal gangue samples were obtained from Xinyang Colliery, which is situated in the west of Shanxi Province of China. The samples were mechanically crushed and then categorized into two groups based on particle size, fine gangue aggregate $(0-5 \mathrm{~mm})$, and coarse gangue
TABLE 1: Chemical composition and physical properties of the materials used.

\begin{tabular}{lccc}
\hline Major element & $\begin{array}{c}\text { Cement } \\
(\%)\end{array}$ & Fly ash (\%) & $\begin{array}{c}\text { Gangue } \\
(\%)\end{array}$ \\
\hline $\mathrm{SiO}_{2}$ & 22.27 & 52.42 & 28.46 \\
$\mathrm{Al}_{2} \mathrm{O}_{3}$ & 5.59 & 32.48 & 16.11 \\
$\mathrm{Fe}_{2} \mathrm{O}_{3}$ & 3.47 & 3.62 & 10.86 \\
$\mathrm{CaO}$ & 65.90 & 3.05 & 7.15 \\
$\mathrm{MgO}$ & 0.81 & 1.01 & 3.50 \\
$\mathrm{TiO}_{2}$ & - & 1.26 & 0.80 \\
$\begin{array}{l}\mathrm{Specific} \text { gravity } \\
\left(\mathrm{g} / \mathrm{cm}^{3}\right)\end{array}$ & 3.1 & 2.2 & 2.0 \\
$\begin{array}{l}\mathrm{Specific} \mathrm{surface} \\
\left(\mathrm{m}^{2} / \mathrm{kg}\right)\end{array}$ & 349 & 415 & 499 \\
$\begin{array}{l}\text { Fineness } \\
(>45 \mu \mathrm{m})(\%)\end{array}$ & 5 & 42.54 & 53.78 \\
$\begin{array}{l}\text { Moisture content } \\
(\%)\end{array}$ & - & 0.56 & 8.0 \\
$\begin{array}{l}\text { Loss on ignition } \\
(\%)\end{array}$ & 2 & 3.8 & - \\
\hline
\end{tabular}

Notes: for measuring $\mathrm{SiO}_{2}$, samples were first burned at $800^{\circ} \mathrm{C}$ to remove organic matter and then measured in a $\mathrm{NaOH}$ solution at $650^{\circ} \mathrm{C}$. All other oxides were measured from samples subject to sealed digestion in $\mathrm{HF}+$ $\mathrm{HNO}_{3}$ at $185^{\circ} \mathrm{C}$.

aggregate $(5-15 \mathrm{~mm})$. According to the Chinese Standard for Technical Requirements and Test Method of Sand and Crushed Stone (or Gravel) for Ordinary Concrete (JGJ522006), the sieving method was used to determine the particle size distribution of the gangue aggregates (Figure 1(a)). The fineness modulus $\mu$ of the fine gangue $(0-5 \mathrm{~mm})$ was 3.02 . Table 1 lists the physical properties of the gangue samples. The $\mathrm{X}$-ray diffraction (XRD) pattern of the mineral composition of the coal gangue samples was collected with a Bruker AXS D8 Advance diffractometer using $\mathrm{Cu} \mathrm{K} \alpha$ radiation (Figure 2(a)). A Thermo Fisher Scientific Thermo iCAP 6300 inductively coupled plasma optical emission spectrometer (ICP-OES) was used to determine the chemical composition of the gangue samples (Table 1).

2.1.2. Fly Ash. The fly ash samples were obtained from the power plant of Xingyang Colliery. A Malvern Mastersizer 2000 Particle Size Analyser was used to analyse the particle size of the fly ash samples (Figure 1(b)). The physical properties of the fly ash samples were analysed according to the Technical Specification for Fly Ash Used in Concrete and Mortar (JGJ28-86). An ICP-OES was used to analyse the chemical composition of the fly ash samples (Table 1). Figure 2(b) shows the mineral composition of the fly ash samples.

2.1.3. Cement and Water. Ordinary Portland cement (Grade 42.5) was used in this study. Table 1 lists the chemical composition and the physical properties of the cement (provided by the manufacturer). The initial and final setting times were $165 \mathrm{~min}$ and $231 \mathrm{~min}$, respectively. The compressive strengths were 18.4 MPa ( $3 \mathrm{~d}$ curing time) and $46.4 \mathrm{MPa}$ (28 d curing 


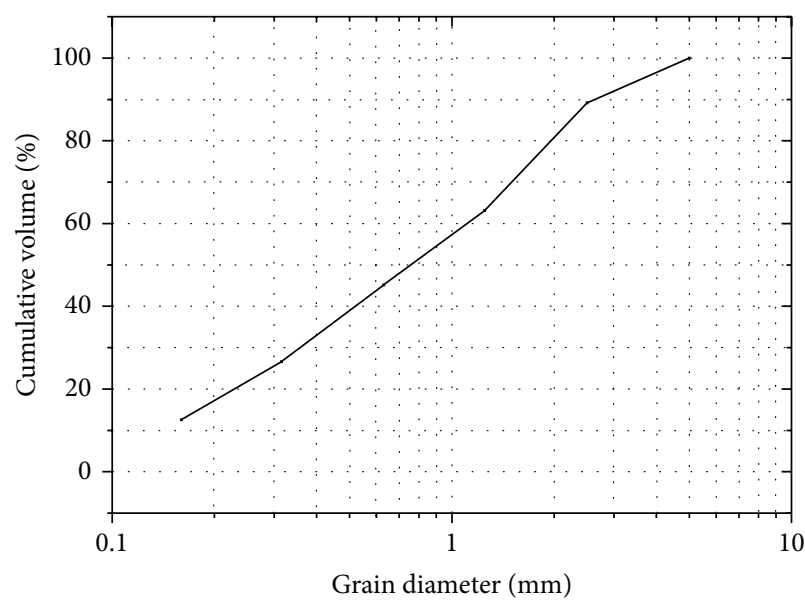

(a)

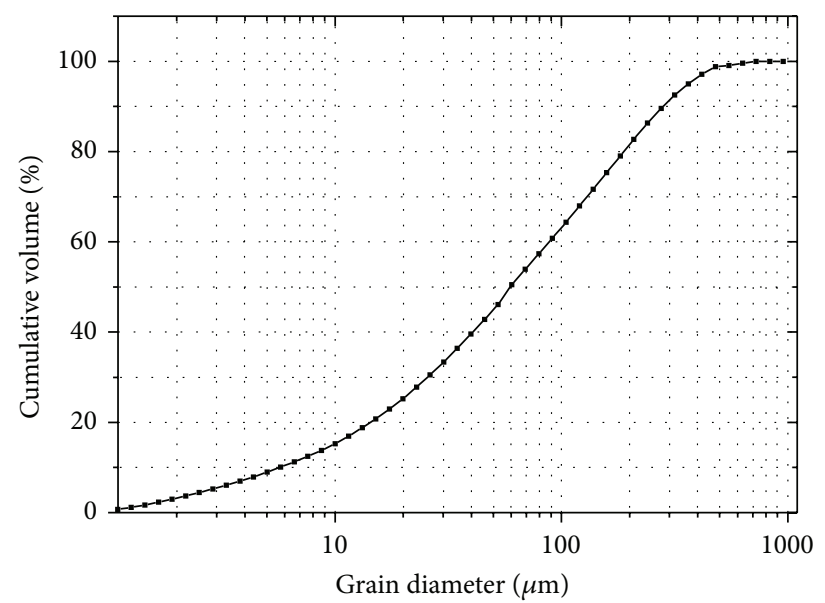

(b)

FIGURE 1: Particle size distribution curves: (a) fine gangue and (b) fly ash.

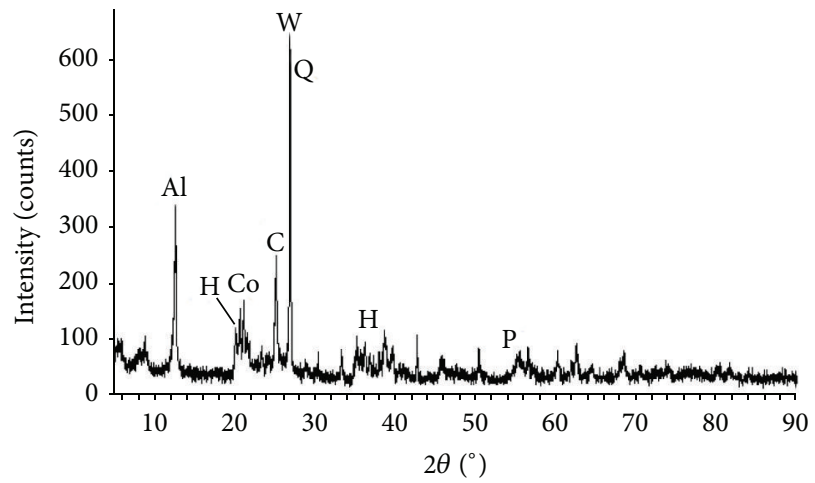

Al: alunogen $\mathrm{Al}_{2}\left(\mathrm{SO}_{4}\right)_{3} \cdot 17 \mathrm{H}_{2} \mathrm{O}$

C: caldecahydrite $\mathrm{CaAl}_{2} \mathrm{O}_{4} \cdot 10 \mathrm{H}_{2} \mathrm{O}$

Co: copiapite $\mathrm{FeFe}_{4}\left(\mathrm{SO}_{4}\right)_{6}(\mathrm{OH})_{2} \cdot 20 \mathrm{H}_{2} \mathrm{O}$

$\mathrm{H}$ : hibonite $\mathrm{CaAl}_{12} \mathrm{O}_{19}$

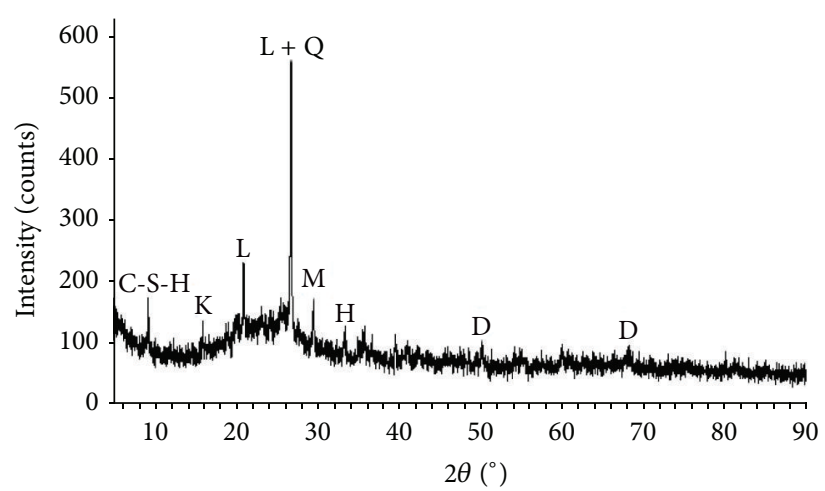

$\mathrm{H}$ : hematite $\mathrm{Fe}_{2} \mathrm{O}_{3}$ $\mathrm{M}$ : magnesium oxide $\mathrm{MgO}$ Q: quartz $\mathrm{SiO}_{2}$
C-S- $\mathrm{H}: \mathrm{Ca}_{2} \mathrm{SiSO}_{4} \cdot 3 \mathrm{H}_{2} \mathrm{O}$

D: dmisteinbergite $\mathrm{Ca}\left[\mathrm{Al}_{2} \mathrm{Si}_{2}\right] \mathrm{O}_{8}$ $\mathrm{K}$ : kirschsteinite $\mathrm{CaFe}+2 \mathrm{SiO}_{4}$

(b)

FIgURE 2: Mineral composition by XRD for (a) coal gangue and (b) fly ash.

time), respectively. The water source used in this study was tap water.

\subsection{Sample Preparation and Test Methods}

2.2.1. Sample Preparation. The raw materials used in the present study were ordinary Portland cement, coal gangue, fly ash, and water. The solid content of the paste mixtures was $80 \%$ by weight. The CGB samples were divided into five groups based on different fine gangue contents. The gangue content (including both fine and coarse gangues) in each group was constantly $950 \mathrm{~kg} / \mathrm{m}^{3}$. The fine gangue $(0-5 \mathrm{~mm})$ occupied 20\% (M1), 30\% (M2), 40\% (M3), 50\% (M4), and $60 \%$ (M5) of the gangue $(0-15 \mathrm{~mm})$ content in each group, respectively. The detailed mixture is given in Table 2 .

The raw materials were mixed according to the designed mix proportions and then mechanically stirred. Next, the slurry was transferred into $10 \times 10 \times 10 \mathrm{~cm}$ testing moulds. After casting, the specimens were cured in a curing room (temperature: $20 \pm 2^{\circ} \mathrm{C}$; humidity: $40 \%$ ) for periods of 3 and 28 days, respectively. To determine the mechanical strengths and electrical properties of CGB specimens after curing, the compressive strength and resistivity tests on the specimens were performed. After 3 and 28 days, samples were taken from the center of cured CGB specimens and immersed in anhydrous ethanol for $24 \mathrm{~h}$. Then, the samples were put in an oven at a temperature of $105^{\circ} \mathrm{C}$ for $16 \mathrm{~h}$ for the following microscopic tests.

2.2.2. Compressive Strength and Resistivity Test. A Wenner dipole array was used to determine the resistivity of the specimens, which were cured for $3 \mathrm{~d}$ and $28 \mathrm{~d}$, respectively. The test voltage was $1 \mathrm{~V}$, and the frequency was $100 \mathrm{~Hz}$. Referring to Gowers and Millard [24], contact resistance 
TABLE 2: Proportions of the mix.

\begin{tabular}{|c|c|c|c|c|c|}
\hline \multirow[b]{2}{*}{ Mixture } & \multirow[b]{2}{*}{ Portland cement $\left(\mathrm{kg} / \mathrm{m}^{3}\right)$} & \multirow[b]{2}{*}{ Water $\left(\mathrm{kg} / \mathrm{m}^{3}\right)$} & \multirow[b]{2}{*}{ Fly ash $\left(\mathrm{kg} / \mathrm{m}^{3}\right)$} & \multicolumn{2}{|c|}{ Gangue $\left(\mathrm{kg} / \mathrm{m}^{3}\right)$} \\
\hline & & & & $\begin{array}{c}\text { Fine } \\
(0-5 \mathrm{~mm})\end{array}$ & $\begin{array}{c}\text { Coarse } \\
(10-15 \mathrm{~mm})\end{array}$ \\
\hline M1 (20\%) & 190 & 380 & 380 & 190 & 760 \\
\hline M2 (30\%) & 190 & 380 & 380 & 285 & 665 \\
\hline M3 (40\%) & 190 & 380 & 380 & 380 & 570 \\
\hline M4 (50\%) & 190 & 380 & 380 & 475 & 475 \\
\hline M5 (60\%) & 190 & 380 & 380 & 570 & 380 \\
\hline
\end{tabular}

was a cause of unstable resistivity. To reduce the effect of contact resistance, copper papers were used as electrodes. A piece of cotton cloth that had been previously immersed in a saturated copper sulphate solution was placed between the copper papers and the specimen.

After resistivity tests, the compressive strength tests were performed on the same CGB samples using a computercontrolled mechanical press, which had a load capacity of $1000 \mathrm{kN}$ and a pressure speed of $6.75 \mathrm{kN}$ per minute according to GB50081. All the experiments were carried out in triplicate and the mean resistivity and compressive strength values were presented in the results.

2.2.3. Microscopic Test. After curing, the CGB particles were subjected to the porosity test using mercury intrusion porosimetry (MIP). A CE Pascal 140/240 porosimeter was used for this test. The CGB particles cured for $3 \mathrm{~d}$ and $28 \mathrm{~d}$ were ground into powder for the X-ray diffraction test. A field emission transmission electron microscopy (FETEM) unit (JSM-7001F) was used for the microscopic observation of the CGB particles cured for $28 \mathrm{~d}$.

Gangue powder $(0-160 \mu \mathrm{m})$ and fly ash were separately immersed in deionised water. The ratio of water to solid mass was $100: 1$. The solution was stirred using a magnetic stirrer for $10 \mathrm{~min}$ and then filtered. An ICP-OES was used to determine the concentrations of major ions in the filtrate.

Solution sample preparation was as follows: after curing for $3 \mathrm{~d}$ and $28 \mathrm{~d}$, the processed CGB particles were ground into powder, which was then immersed in deionised water. The ratio of water to solid mass was $100: 1$. The solution was stirred using a magnetic stirrer for $10 \mathrm{~min}$. To prevent the reaction between the particles and water, the solution was filtered. The concentrations of the major ions in the filtrate were immediately measured using the ICP-OES. The testing temperature of the solution was $20 \pm 1^{\circ} \mathrm{C}$. The changing trend of the ion concentrations in the material solution was used to determine the changing regularity of the ion concentrations in the pore solution because of the correlation between the two solutions in $\mathrm{pH}$ and ion concentration $[25,26]$. However, because of the difference in the pore water content caused by different curing times, there were differences between the ion concentrations of the pore solution and the material solution. The pore solution should not be collected using the high-pressure extraction method $[27,28]$, because the high pressure could cause the fragmentation of the gangue and the dissolution of active substances.

\section{Results and Discussion}

3.1. Effects of Fine Gangue Content on Microscopic Properties of CGB. The hydration and pozzolanic reaction occurred among the minerals in CGB. The hydration products contain hydrated calcium silicate $(\mathrm{C}-\mathrm{S}-\mathrm{H})$ gel, calcium hydroxide (portlandite $\mathrm{Ca}(\mathrm{OH})_{2}$ ), AFt (ettringite, etc.), or AFm (monosulphate, etc.) phases. Then, the active $\mathrm{Si}^{4+} \mathrm{Al}^{3+} \mathrm{Fe}^{3+}$ irons, in which gangue and fly ash are enriched, react with portlandite to form AFt or AFm [29-31].

Figure 3 shows the XRD patterns of the mineral composition of the CGB samples with a fine gangue content of 20-60\% cured for $3 \mathrm{~d}$ and $28 \mathrm{~d}$, respectively. The diffraction angles of the mineral crystals with different fine gangue contents cured for the same time were approximately the same. However, their intensities differed, which indicated that the change in fine gangue content did not affect the material's mineral composition of the material but the mineral content differed among the samples. The reaction products $\mathrm{C}-\mathrm{S}-\mathrm{H}$, $\mathrm{AFt}$, and $\mathrm{Ca}(\mathrm{OH})_{2}$ were detected in the samples that were cured for $3 \mathrm{~d}$ (Figure $3(\mathrm{a})$ ). The peak intensity of $\mathrm{Ca}(\mathrm{OH})_{2}$ crystals at $52^{\circ}$ decreased with the increase in fine gangue content. The decrease in $\mathrm{Ca}(\mathrm{OH})_{2}$ content in material was related to the consumption of $\mathrm{Ca}(\mathrm{OH})_{2}$ in the pozzolanic reaction. The increasing fine gangue content led to amplifying the specific contact surface area between the gangue and $\mathrm{Ca}(\mathrm{OH})_{2}$. The mineral composition of the samples cured for $28 \mathrm{~d}$ (Figure 3(b)) included C-S-H and AFt. No $\mathrm{Ca}(\mathrm{OH})_{2}$ crystal was detected in the XRD because of the low cement content and high pozzolanic reaction degree after $28 \mathrm{~d}$ of curing time. The peak intensities of C-S-H gel at $22.3^{\circ}$ and AFt phase at $31.8^{\circ}$ increased with the increase in fine gangue content, due to the fact that increasing quantity of soluble active irons generates more pozzolanic products content.

Figure 4 shows surface morphology of the gangue particles in the CGB samples at 20\%, 40\%, and 60\% fine gangue content. When the fine gangue content was $20 \%$, the surface of gangue was covered by needle-like, columnar, floccuslike, and petal-like pozzolanic products (Figure 4(a)). When gangue was dissolved in water, active ions $\left(\mathrm{Si}^{4+}, \mathrm{Al}^{3+}\right.$, and $\mathrm{Fe}^{3+}$ ) precipitated on the gangue's surface. Then, a pozzolanic reaction occurred between these ions and $\mathrm{Ca}(\mathrm{OH})_{2}$, and the products of this reaction accumulated on the surface of the gangue particles. When the fine gangue content was $40 \%$ (Figure $4(\mathrm{~b})$ ), the surface of gangue was partially covered by floccus matter, whereas some lamellar minerals were 


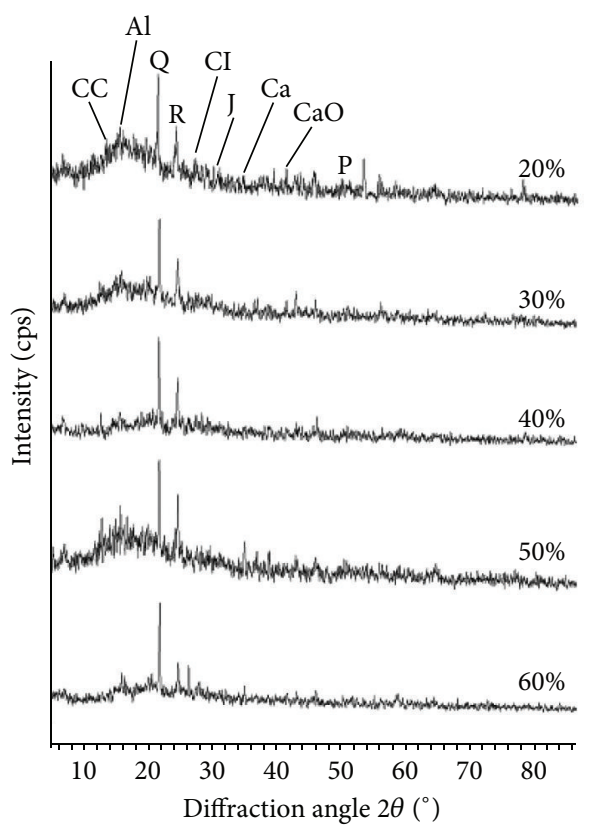

CC: garronite calcian $\mathrm{Ca}_{3} \mathrm{Al}_{6} \mathrm{Si}_{9} \mathrm{O}_{30} \cdot 15 \mathrm{H}_{2} \mathrm{O}$

$\mathrm{Al}$ : aluminium oxide $\mathrm{Al}_{2} \mathrm{O}_{3}$

Q: quartz $\mathrm{SiO}_{2}$

$\mathrm{R}$ : rankinite $\mathrm{Ca}_{3} \mathrm{Si}_{2} \mathrm{O}_{7}$

CI: calcium oxide $\mathrm{CaFe}_{4} \mathrm{O}_{7}$

$\mathrm{J}$ : julgoldite $\left(\mathrm{Fe}^{2+}\right) \mathrm{Ca}_{2}(\mathrm{Fe}, \mathrm{Al})_{3}\left(\mathrm{SiO}_{4}\right)\left(\mathrm{Si}_{2} \mathrm{O}_{7}\right)(\mathrm{OH})_{2} \cdot \mathrm{H}_{2} \mathrm{O}$

Ca: calcium Silicate $\mathrm{Ca}_{2} \mathrm{SiO}_{4}$

$\mathrm{CaO}$ : calcium oxide $\mathrm{CaO}$

P: portlandite $\mathrm{Ca}(\mathrm{OH})_{2}$

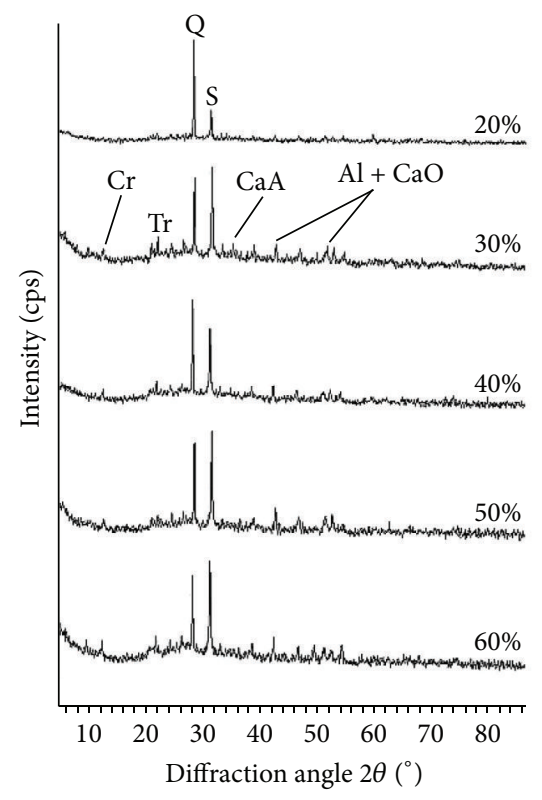

Al: aluminium oxide $\mathrm{Al}_{2} \mathrm{O}_{3}$

Q: quartz $\mathrm{SiO}_{2}$

S: stilpnomelane $\mathrm{Ca}_{4} \mathrm{Fe}_{47} \mathrm{Si}_{72} \mathrm{O}_{180}(\mathrm{OH})_{36} \cdot x \mathrm{H}_{2} \mathrm{O}$

Cr: cronstedtite- $3 \mathrm{~T} \mathrm{Fe}_{3}\left[\mathrm{Si}_{2} \mathrm{O}_{5}\right](\mathrm{OH})_{4}$

Tr: truscottite $\mathrm{Ca}_{14} \mathrm{Si}_{24} \mathrm{O}_{58}(\mathrm{OH})_{8} \cdot 2 \mathrm{H}_{2} \mathrm{O}$

$\mathrm{CaA}$ : calcium aluminium oxide hydrate $\mathrm{Ca}_{2} \mathrm{Al}_{2} \mathrm{O}_{5} \cdot 8 \mathrm{H}_{2} \mathrm{O}$

$\mathrm{CaO}$ : calcium oxide $\mathrm{CaO}$

(a)

(b)

FIGURE 3: XRD results of samples at 20\%-60\% fine gangue dosage at (a) $3 \mathrm{~d}$ and (b) $28 \mathrm{~d}$.

distributed on the surface. When the $\mathrm{Ca}(\mathrm{OH})_{2}$ content was fixed, the specific surface area of gangue of fine particle size increased, and the generated pozzolanic products could not fully cover the surface of gangue of fine particle size. When the fine gangue content was $60 \%$ (Figure $4(\mathrm{c})$ ), lamellar and granular gangue in its initial form was observed on the surface of particles, which indicated that some minerals on the surface of gangue of fine particle size did not participate in the pozzolanic reaction. With the increase in fine gangue content, the exposed fine gangue minerals in CGB also increased.

Figure 5 shows that the porosity of the material cured for $28 \mathrm{~d}$ was smaller than that of the material cured for $3 \mathrm{~d}$. Because the hydration and pozzolanic reaction products continuously filled up the pores between the cemented material and the gangue, the overall porosity decreased with the increasing curing time $[32,33]$.

The total porosity curve at 3 and 28 days is presented in Figure 5 which clearly showed that fine gangue addition produces less pores. At the fine gangue content between $20 \%$ and $40 \%$, the porosity of the CGB samples of 3 and 28 days decreased from 39.97 and $34.34 \%$ to 35.28 and $30.16 \%$ corresponding to $11.72 \%$ and $12.19 \%$ losses of porosity. At the fine gangue content between $40 \%$ and $60 \%$, the porosity of the CGB samples of 3 and 28 days decreased from 35.28 and $30.16 \%$ to 32.91 and $28.30 \%$ corresponding to $6.72 \%$ and $3.62 \%$ losses of porosity. Fine gangue plays double roles during the pozzolanic reaction and pore structure formation processes. The bigger pore space among the coarse gangues is filled with finer gangues. The finer gangue content signified higher reaction degree and is related more to reaction products packing pattern.

Differential distribution curve (Figure 6) is presented in order to estimate and evaluate the pore structure of the CGB at 28 days. With the increase in fine gangue content, the volume of the capillary-size pores in the range of 0 $2,000 \mathrm{~nm}$ gradually decreased. With the increase in porosity, the number of pores increased, which facilitated the connection of the pore solution. Additionally, a conductive network was formed inside the CGB, which enhanced the current transport capacity of the pore solution. To estimate the critical pore size $\left(d_{\mathrm{cr}}\right)$ the differential distribution curve was plotted where the critical pore size corresponds to the diameter that the distribution presents maximum. The critical pore size controls the transmissivity of the material [34]. The critical pore diameter is the most frequently occurring diameter in the interconnected pores that allows maximum percolation of chemical species through the CGB [35]. Figure 6 


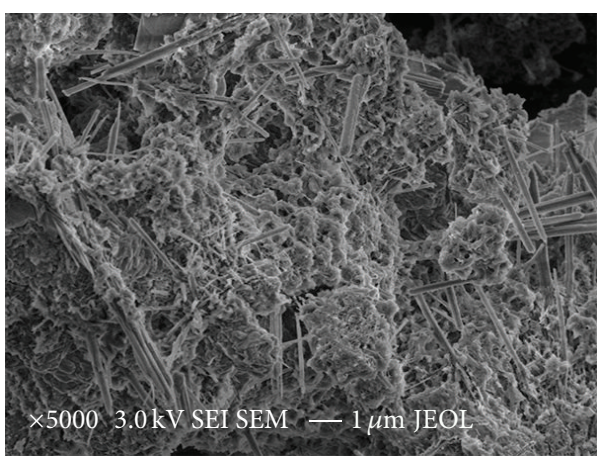

(a)



(b)

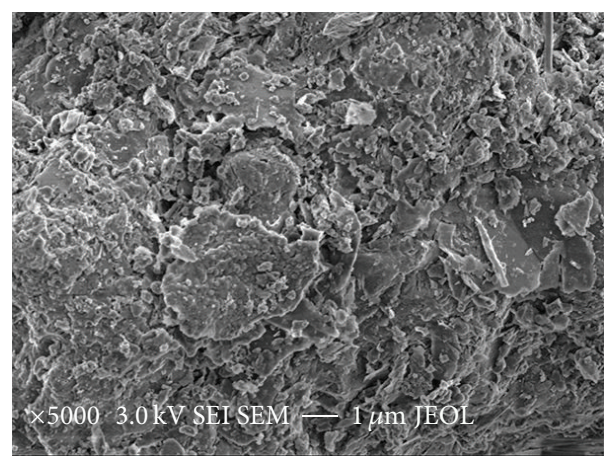

(c)

FIGURE 4: Surface morphology of the gangue particles in CGB samples at fine gangue contents of (a) 20\%, (b) $40 \%$, and (c) $60 \%$.



FIGURE 5: MIP porosity of CGB at $3 \mathrm{~d}$ and $28 \mathrm{~d}$.

indicates that as fine gangue content increases critical diameter decreased. This leads to the conclusion that fine gangue addition in CGB produces less interconnected pores in CGB but of the same magnitude.

Table 3 shows that the fly ash and the gangue solution contained $\mathrm{Al}^{3+}, \mathrm{Fe}^{3+}$, and $\mathrm{Si}^{4+}$ that could participate in the pozzolanic reaction. $\mathrm{Al}^{3+}, \mathrm{Fe}^{3+}$, and $\mathrm{Si}^{4+}$ contained independent cations and complex ions. The concentration of these cations and ions could be used to determine the active $\mathrm{SiO}_{2}$, $\mathrm{Al}_{2} \mathrm{O}_{3}$, and $\mathrm{Fe}_{2} \mathrm{O}_{3}$ content. The concentration of $\mathrm{Fe}^{3+}$ reached $6.96 \mathrm{mg} / \mathrm{L}$ in the gangue solution, whereas the concentration of $\mathrm{Al}^{3+}$ reached $4.594 \mathrm{mg} / \mathrm{L}$ in the fly ash solution. The $\mathrm{Ca}^{2+}$ in the gangue and the fly ash solutions was relatively

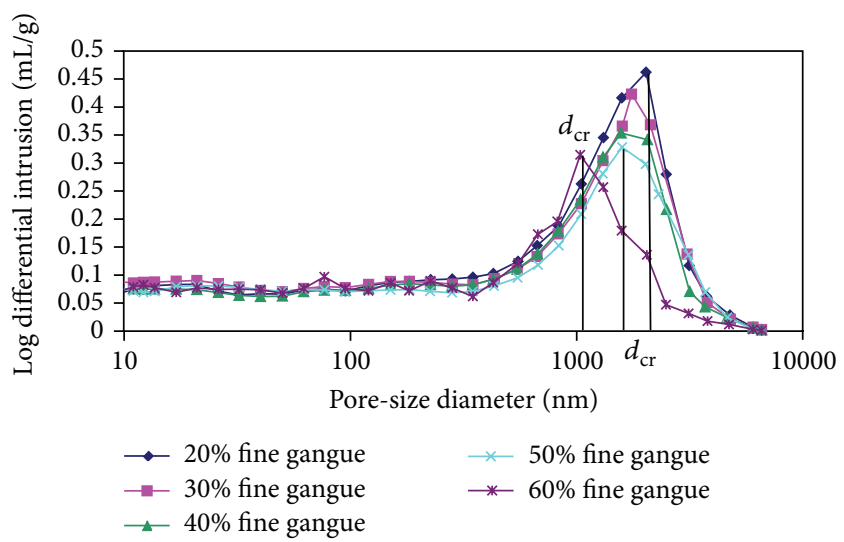

Figure 6: Differential distribution curve at 20-60\% fine gangue content at $28 \mathrm{~d}$.

concentrated. In addition, the concentrations of $\mathrm{Na}^{+}$and $\mathrm{K}^{+}$ were similar.

The pore solution of the CGB primarily contained $\mathrm{Na}^{+}$, $\mathrm{K}^{+}, \mathrm{Ca}^{2+}, \mathrm{Mg}^{2+}, \mathrm{Al}^{3+}, \mathrm{Fe}^{3+}, \mathrm{Si}^{4+}, \mathrm{SO}_{4}{ }^{2-}, \mathrm{Al}(\mathrm{OH})_{4}{ }^{-}, \mathrm{H}_{3} \mathrm{SiO}_{4}{ }^{-}$, $\mathrm{OH}^{-}$, and $\left[\mathrm{FeO}_{2}(\mathrm{OH})\right]^{2-}$, which originated in the gangue, the dissolution of the fly ash, and the hydrolysis between the hydration and the pozzolanic reaction products [36].

Table 4 lists the change of the concentrations of seven major ions in the pore solution after curing for $3 \mathrm{~d}$ and $28 \mathrm{~d}$. After curing for $3 \mathrm{~d}$, the concentrations of $\mathrm{Si}^{4+}, \mathrm{Fe}^{3+}, \mathrm{Al}^{3+}$, and 
TABLE 3: Concentrations of major ions in the raw material solution.

\begin{tabular}{lccccccc}
\hline Elements $(\mathrm{mg} / \mathrm{L})$ & $\mathrm{Mg}$ & $\mathrm{Si}$ & $\mathrm{Fe}$ & $\mathrm{Al}$ & $\mathrm{Ca}$ & $\mathrm{K}$ & $\mathrm{Na}$ \\
\hline Coal gangue & 3.07 & 0.36 & 6.96 & 0.284 & 233 & 0.409 & 0.986 \\
Fly ash & 1.20 & 0.413 & 0.006 & 4.594 & 47.7 & 0.426 & 1.08 \\
\hline
\end{tabular}

TABLE 4: Active ion content at 3-day and 28-day curing times.

\begin{tabular}{|c|c|c|c|c|c|c|c|c|}
\hline & Compound & $\mathrm{Mg}$ & $\mathrm{Si}$ & $\mathrm{Fe}$ & $\mathrm{Al}$ & $\mathrm{Ca}$ & $\mathrm{K}$ & $\mathrm{Na}$ \\
\hline \multirow{5}{*}{$\begin{array}{l}3 \mathrm{~d} \\
(\mathrm{mg} / \mathrm{L})\end{array}$} & $20 \%$ & 0.664 & 1.76 & 0.447 & 6.966 & 86.5 & 2.28 & 2.94 \\
\hline & $30 \%$ & 0.596 & 1.69 & 0.438 & 6.758 & 77.6 & 2.43 & 2.77 \\
\hline & $40 \%$ & 0.650 & 1.70 & 0.412 & 6.638 & 74.3 & 2.34 & 2.82 \\
\hline & $50 \%$ & 0.601 & 1.56 & 0.387 & 6.495 & 72.1 & 2.18 & 2.88 \\
\hline & $60 \%$ & 0.624 & 1.47 & 0.342 & 5.786 & 63.7 & 2.08 & 2.68 \\
\hline \multirow{5}{*}{$\begin{array}{l}28 \mathrm{~d} \\
(\mathrm{mg} / \mathrm{L})\end{array}$} & $20 \%$ & 0.748 & 0.468 & 0.327 & 7.452 & 47.0 & 2.62 & 2.57 \\
\hline & $30 \%$ & 0.687 & 0.547 & 0.334 & 7.714 & 49.6 & 2.37 & 2.63 \\
\hline & $40 \%$ & 0.674 & 0.608 & 0.332 & 8.007 & 48.7 & 2.57 & 2.84 \\
\hline & $50 \%$ & 0.746 & 0.584 & 0.437 & 8.125 & 51.6 & 2.18 & 2.71 \\
\hline & $60 \%$ & 0.689 & 0.617 & 0.441 & 8.131 & 52.4 & 2.60 & 2.64 \\
\hline
\end{tabular}

$\mathrm{Ca}^{2+}$ decreased with the increase in fine gangue content, the concentrations of $\mathrm{K}^{+}, \mathrm{Na}^{+}$, and $\mathrm{Mg}^{2+}$ did not change, and the overall ion concentration decreased. After curing for $28 \mathrm{~d}$, the concentrations of $\mathrm{Si}^{4+}, \mathrm{Fe}^{3+}, \mathrm{Al}^{3+}$, and $\mathrm{Ca}^{2+}$ increased and the overall ion concentration increased.

The hydration and the pozzolanic reactions are the primary reactions that occur in CGB. The dissolving and the reacting doses collectively affect the concentrations of the active ions. In the beginning, when the raw materials are mixed, a hydration reaction occurs in the cement. Active ions dissolve out and accumulate on the surface of gangue particles. The dissolving dose is greater than the reacting dose $(24 \mathrm{~h})$. When the hydration reaction continues, more $\mathrm{Ca}(\mathrm{OH})_{2}$ is generated. With the increase in fine gangue content, the specific surface area increases. Therefore, the reaction contact area between $\mathrm{Ca}(\mathrm{OH})_{2}$ and gangue increases. The concentrations of $\mathrm{Ca}^{2+}, \mathrm{OH}^{-}$, and active ions decrease. The gel generated from the reaction covers the surface of the particles, which prevents dissolution. At this time, the reacting dose is greater than the dissolving dose after curing for $3 \mathrm{~d}$. After curing for $28 \mathrm{~d}$, the hydration and the pozzolanic reaction level off. The change in the concentrations of the ions is primarily caused by precipitation. Therefore, with the increase in fine gangue content, the specific surface area increases, the quantity of the exposed minerals on the surface of gangue increases, and the number of dissolved ions increases.

\subsection{Effects of Fine Gangue Content on Compressive Strength} of CGB. Fine gangue content plays an important role in the mechanical behavior of CGB samples. Figure 7 shows the development of mechanical strength of CGB samples produced from $20 \%-60 \%$ fine gangue content at 3- and 28 day curing time. The increase in the strengths of the CGB samples was noted to peak at the fine gangue usage of $40 \%$; thereafter, a trend of decline was apparent, irrespective

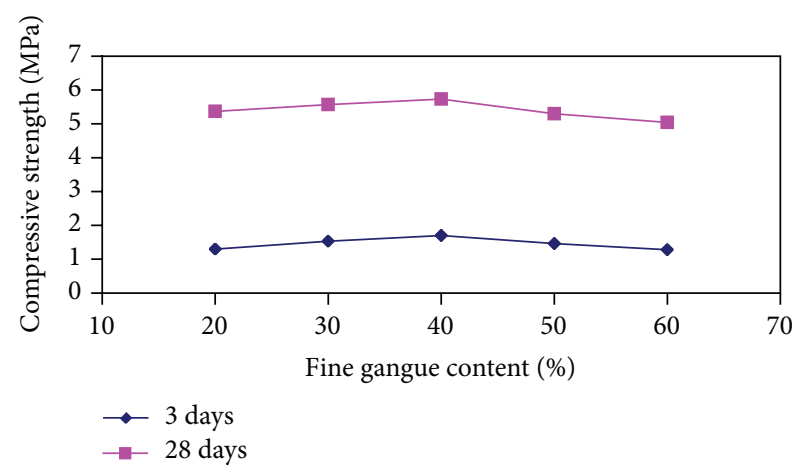

Figure 7: Compressive strength of CGB samples with 20-60\% fine gangue contents at 3 and 28 days.

of curing time. At the fine gangue content between $20 \%$ and $40 \%$, the strengths of the CGB samples of 3 and 28 days increased from 1.3 and $5.37 \mathrm{MPa}$ to 1.7 and $5.73 \mathrm{MPa}$ corresponding to $30.8 \%$ and $6.7 \%$ gains of strength. The reason is that increasing the gangues fineness leads to a lower porosity and more reaction products which reduce the porosity and enhance the bonding formation between the gangue particles. Previous research indicated that the surface texture of the aggregate plays an important role in compressive strength of mortars [37, 38]. The grip between the paste and the aggregate at the interfacial zone will be improved when a rougher texture aggregate is used, thereby leading to an increase in compressive strength [39]. As the fine gangue content increased from $40 \%$ to $60 \%$, the strengths of the CGB samples of 3 and 28 days decreased from 1.7 and 5.73 MPa to 1.28 and 5.04 MPa corresponding to about $24.7 \%$ and $12 \%$ losses of strength. This is because the more products which covered the gangue particles surface exceed a threshold (Figure 4), which is not in favor of bonding with interspace between adjacent fine gangue grains. The rough 


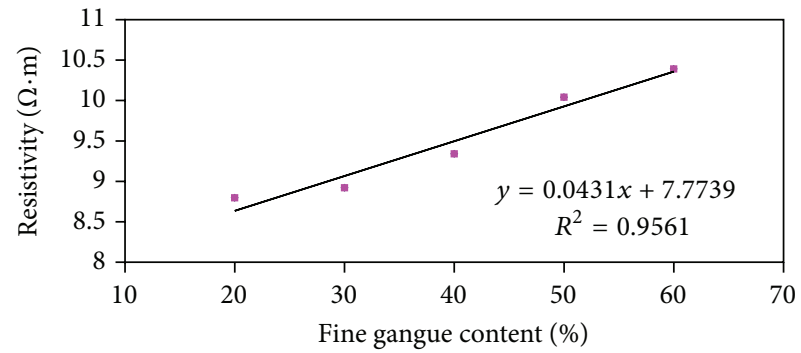

(a)



(b)

FIGURE 8: Relationship between resistivity and fine gangue content for CGB samples at curing times of (a) $3 \mathrm{~d}$ and (b) $28 \mathrm{~d}$.

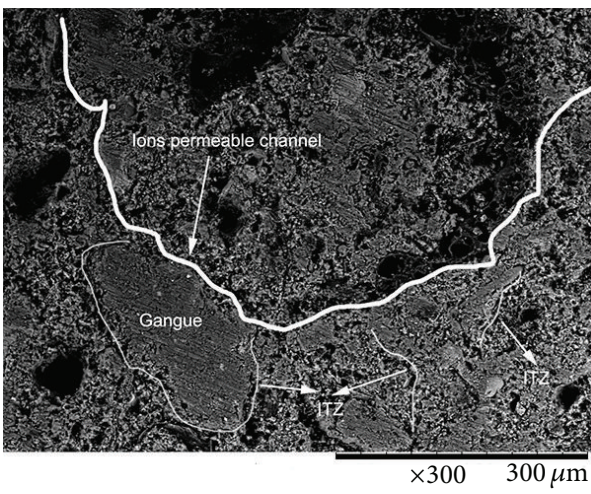

(a)

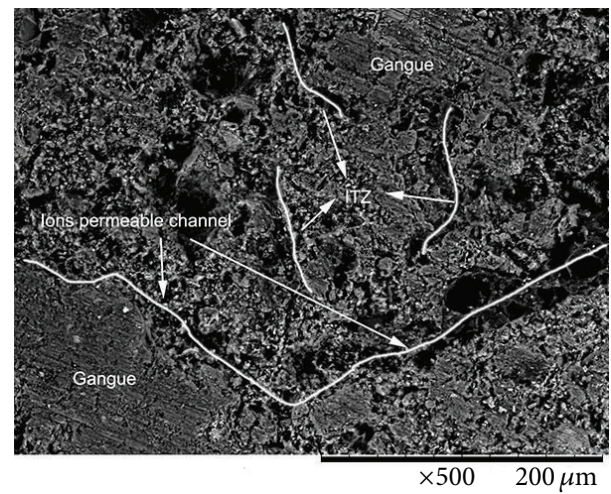

(b)

FIGURE 9: The interfacial transition zone (ITZ) between paste and gangue in CGB specimen at 28 days.

and angular nature of fine gangue affects the compaction of the mixes in the fresh state. Torkittikul and Chaipanich [40] explained that the decrease in strength when using fine gangue content at $40-60 \%$ of the total gangue by weight may be due to the difficulty in the compaction of the harsh mortar. The mechanical behaviour is taken into account; the optimum $40 \%$ fine gangue content is used in CGB.

\subsection{Effect of Fine Gangue Content on the Resistivity of CGB.} Figure 8 shows the relationship between resistivity and fine gangue content after curing for $3 \mathrm{~d}$ and $28 \mathrm{~d}$ when the voltage was $1 \mathrm{~V}$ and the frequency was $100 \mathrm{~Hz}$. Figure 8(a) shows that, with the increase in fine gangue content, the resistivity also increased after curing for $3 \mathrm{~d}$. Figure 8(b) indicates that increasing fine gangue results in the reduction of resistivity in CGB samples after curing for $28 \mathrm{~d}$. The resistivity of the gangue was measured to be $1 \times 10^{7} \Omega \cdot \mathrm{m}$, which is far greater than the resistivity of the measured CGB samples. The presence of gangues in the CGB matrix has two opposite effects on the transport properties [41]. The dilution and tortuosity effects reduce CGB permeability while the interface transition zone (ITZ) and percolation effects increase permeability (Figure 9). In addition, the diffusivity of CGB on pore structure can attribute to the effect of capillary porosity and connectivity of these capillary pores. Therefore, the resistivity of the CGB is related to the porosity, the pore-size distribution, the ion concentrations, and the ITZ effect [42-44].
After curing for $3 \mathrm{~d}$, with the increase in fine gangue content, the concentrations of the ions in the pore solution decreased, which caused the decrease in the current transport capacity of the solution, and the current transport in the pore structure became more difficult, which caused the increase in resistivity. After curing for $28 \mathrm{~d}$, because of the increase in the concentrations of the ions in the pore solution, the current transport capacity of the solution increased, which caused the decrease in resistivity. The pore structure had a limited impact on the resistivity of the CGB sample. However, when the gangue size decreased under a constant volume, the porous interfacial transition zone (ITZ) content would increase. The ITZ and percolation effects increase the CGB permeability; moreover, ions transport will be significantly enhanced [45].

3.4. Relationships between Compressive Strength and Resistivity. The raw materials used in CGB of the present study resemble those used for concrete. However, the cement content for CGB is less than that for concrete, and the fine gangue for CGB acted as cementitious material and fine aggregate. As shown in Figures 7 and 8, the resistivity and strength of the tested CGB changed with increase in fine gangue content. The resistivity of the CGB is related to the porosity, pore-size distribution, ion concentration, and ITZ effect. At 3-day curing time, there were high porosity and much water in the pore space of CGB samples, which minimized the effect of ITZ on the current flow. The decreasing ion concentration (Table 4) and porosity with increase in fine 


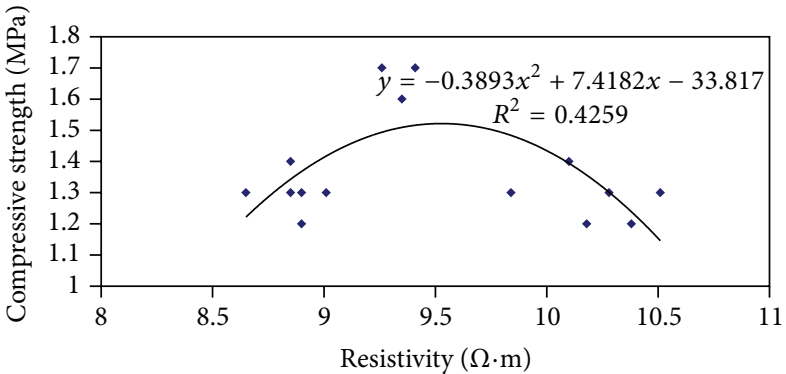

(a)

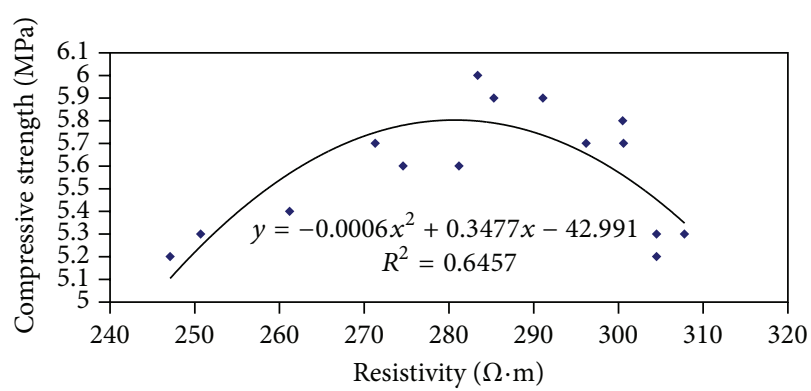

(b)

FIGURE 10: Relationships between strength and resistivity for CGB samples with 20-60\% fine gangue content at (a) 3 and (b) 28 days.

gangue content might be the main cause for the increasing resistivity (Figure $8(\mathrm{a})$ ), as the electrical resistivity of CGB is related to the porosity and the ions concentration of the pore solution. At 28 days, the degree of CGB saturation was lower than CGB saturation at early stage. The resistivity of CGB was influenced by the ions concentration of pore solution and ions transport channels. Ions transport channels consisted of pore structure and ITZ, the pore structure for MIP exhibits a statistical gradient of bulk paste of CGB which is outward from the actual paste-aggregate interface, and the effects of the ITZ are that the movement of water and ions through the "ITZ paste" is much more rapid than through the "bulk paste" [46]. In short, the ITZ would be the main factor on ions transport (Figure 9). With fine gangue content, the ITZ content increased and the fine gangues tended to be closely spaced so that the adjacent ITZs overlap in space. In addition, the ions concentration of pore solution increased with fine gangue content (Table 4). As a result, the capacity of ions transport was significantly enhanced and resistivity of CGB was decreased.

The factors influencing the compressive strength include interfacial zone, porosity, hydration, and content of pozzolanic reaction products. Increasing fine gangue content from $20 \%$ to $40 \%$ leads to a low porosity and many reaction products. This improves the CGB compaction and enhances the bonding formation between the gangue particles, causing increase in compressive strength. With further increase in fine gangue content from $40 \%$ up to $60 \%$, the reaction products could not cover the surface of fine gangues, leading to reduction of bonding between gangue particles. This caused a reduction of compressive strength.

According to Wei et al. [20], Lübeck et al. [21], and Ferreira and Jalali [22], there is a linear relationship between compressive strength and concrete resistivity when concrete mixtures are made with the same cementitious materials. This is because both compressive strength and electrical resistivity are dependent on the continuous hydration of cement. In this study, however, there exists no sensible correlation between compressive strength and CGB resistivity as shown in Figure 10. On one hand, the compressive strength of CGB was influenced by reaction products, porosity, and surface of gangues. On the other hand, the resistivity of CGB was affected by ions concentration of pore solution and ITZ effects. The above two sides do not work in the same direction during CGB curing periods. This may be the reason for the concave patterns in Figure 10. As there is no obvious correlation between the compressive strength and resistivity of CGB, it is thought not proper to use electrical resistivity as an indicator for evaluation of compressive strength of CGB in engineering practice.

\section{Conclusions}

In this study, the effect of fine gangue content on the strength, resistivity, and microscopic properties of CGB was evaluated. Based on the foregoing discussion, several main conclusions may be drawn as follows:

(1) The compressive strength of CGB increases with fine gangue content increasing up to $40 \%$. After that finer gangue leads to decrease in the compressive strength.

(2) At 3 days of curing time, an increasing trend of CGB resistivity was noted with increase in fine gangue content, which could be attributed to the denser pore structure and higher ions concentrations of pore solution.

(3) At 28 days, the resistivity of CGB decreased with increase in fine gangue content, which may be attributed to the enhanced interfacial transition zone and ion concentration of pore solution.

(4) The nonlinear correlations between resistivity and compressive strength of CGB indicate that it is not proper to use the former to estimate the latter. This is different from what have been found in concrete study, where compressive strength seems proportional to resistivity. The fine gangue works not only as aggregates but also as cementitious materials in CGB. It influences not only the ITZ but also the ion concentration and content of chemical reaction products. The unbalanced change of these three with fine gangue content finally leads to a concave-shaped correlation between compressive strength and the resistivity of CGB.

\section{Conflict of Interests}

The authors declare that there is no conflict of interests regarding the publication of this paper. 


\section{Acknowledgments}

This work was financially supported by the National Natural Science Foundation of China (51174142 and 51422404), National Science Support Panning of China (2009BAB48B02 and 2009BAB48B03), Program for New Century Excellent Talents in University of Chinese Ministry of Education (NCET-11-1036) and the Fok Ying Tung Education Foundation (132023), Scientific and Technological Industrialization Environment Construction Project of Shanxi Province (2013071050), and Postgraduate Innovate Project of Shanxi Province (02100489).

\section{References}

[1] N. Zhang, H. H. Sun, X. M. Liu, and J. X. Zhang, "Early-age characteristics of red mud-coal gangue cementitious material," Journal of Hazardous Materials, vol. 167, no. 1-3, pp. 927-932, 2009.

[2] Z. Bian, X. Miao, S. Lei, S.-E. Chen, W. Wang, and S. Struthers, "The challenges of reusing mining and mineral-processing wastes," Science, vol. 337, no. 6095, pp. 702-703, 2012.

[3] C. Li, J. H. Wan, H. H. Sun, and L. T. Li, "Investigation on the activation of coal gangue by a new compound method," Journal of Hazardous Materials, vol. 179, no. 1-3, pp. 515-520, 2010.

[4] D. Landriault, "Backfill in underground mining," in Underground Mining Methods: Engineering Fundamentals and International Case Studies, W. A. Hustrulid and R. L. Bullock, Eds., pp. 601-614, Society for Mining, Metallurgy and Exploration, Littleton, Colo, USA, 2001.

[5] D. Hewitt, S. Allard, and P. Radziszewski, "Pipe lining abrasion testing for paste backfill operations," Minerals Engineering, vol. 22, no. 12, pp. 1088-1090, 2009.

[6] A. Kesimal, B. Ercikdi, and E. Yilmaz, "The effect of desliming by sedimentation on paste backfill performance," Minerals Engineering, vol. 16, no. 10, pp. 1009-1011, 2003.

[7] E. Yilmaz, A. Kesimal, and B. Ercikdi, "Strength properties in varying cement dosages for paste backfill samples," in Proceedings of the 10th International Conference on Tailings and Mine Waste, Balkema, Swets and Zeitlinger, pp. 109-114, Lisse, The Netherlands, October 2003.

[8] W. Guo, D. X. Li, J. H. Chen, and N. R. Yang, "Structure and pozzolanic activity of calcined coal gangue during the process of mechanical activation," Journal Wuhan University of Technology, Materials Science Edition, vol. 24, no. 2, pp. 326-329, 2009.

[9] Z.-D. Cui and H.-H. Sun, "The preparation and properties of coal gangue based sialite paste-like backfill material," Journal of the China Coal Society, vol. 35, no. 6, pp. 896-899, 2010.

[10] B. C. Zheng, H. Q. Zhou, and R. J. He, "Experimental research on coal gangue paste filling material," Journal of Mining and Safety Engineering, vol. 23, no. 4, pp. 460-463, 2006.

[11] M. Fall, J. C. Célestin, M. Pokharel, and M. Touré, "A contribution to understanding the effects of curing temperature on the mechanical properties of mine cemented tailings backfill," Engineering Geology, vol. 114, no. 3-4, pp. 397-413, 2010.

[12] B. Ercikdi, H. Baki, and M. Izki, "Effect of desliming of sulphiderich mill tailings on the long-term strength of cemented paste backfill," Journal of Environmental Management, vol. 115, pp. 513,2013

[13] F. Cihangir, B. Ercikdi, A. Kesimal, A. Turan, and H. Deveci, "Utilisation of alkali-activated blast furnace slag in paste backfill of high-sulphide mill tailings: effect of binder type and dosage," Minerals Engineering, vol. 30, pp. 33-43, 2012.

[14] R. B. Polder, "Test methods for on site measurement of resistivity of concrete-a RILEM TC-154 technical recommendation," Construction and Building Materials, vol. 15, no. 2-3, pp. 125-131, 2001.

[15] C. Andrade, "Model for prediction of reinforced concrete service life based on electrical resistivity," Ibracon Structures and Materials Journal, vol. 1, no. 1, 2005.

[16] L. Z. Xiao and Z. J. Li, "Early-age hydration of fresh concrete monitored by non-contact electrical resistivity measurement," Cement and Concrete Research, vol. 38, no. 3, pp. 312-319, 2008.

[17] W.-M. Hou, P.-K. Chang, and C.-L. Hwang, "A study on anticorrosion effect in high-performance concrete by the pozzolanic reaction of slag," Cement and Concrete Research, vol. 34, no. 4, pp. 615-622, 2004.

[18] A. L. G. Gastaldini, G. C. Isaia, T. F. Hoppe, F. Missau, and A. P. Saciloto, "Influence of the use of rice husk ash on the electrical resistivity of concrete: a technical and economic feasibility study," Construction and Building Materials, vol. 23, no. 11, pp. 3411-3419, 2009.

[19] A. Princigallo, K. Van Breugel, and G. Levita, "Influence of the aggregate on the electrical conductivity of Portland cement concretes," Cement and Concrete Research, vol. 33, no. 11, pp. $1755-1763,2003$.

[20] X. S. Wei, L. Z. Xiao, and Z. J. Li, "Prediction of standard compressive strength of cement by the electrical resistivity measurement," Construction and Building Materials, vol. 31, pp. 341-346, 2012.

[21] A. Lübeck, A. L. G. Gastaldini, D. S. Barin, and H. C. Siqueira, "Compressive strength and electrical properties of concrete with white Portland cement and blast-furnace slag," Cement and Concrete Composites, vol. 34, no. 3, pp. 392-399, 2012.

[22] R. M. Ferreira and S. Jalali, "NDT measurements for the prediction of 28-day compressive strength," NDT \& E International, vol. 43, no. 3, pp. 55-61, 2010.

[23] A. A. Ramezanianpour, A. Pilvar, M. Mahdikhani, and F. Moodi, "Practical evaluation of relationship between concrete resistivity, water penetration, rapid chloride penetration and compressive strength," Construction and Building Materials, vol. 25, no. 5, pp. 2472-2479, 2011.

[24] K. R. Gowers and S. G. Millard, "Measurement of concrete resistivity for assessment of corrosion severity of steel using Wenner technique," ACI Materials Journal, vol. 96, no. 5, pp. 536-541, 1999.

[25] Y. Xi, D. D. Siemer, and B. E. Scheetz, "Strength development, hydration reaction and pore structure of autoclaved slag cement with added silica fume," Cement and Concrete Research, vol. 27, no. 1, pp. 75-82, 1997.

[26] Q. Pu, L. H. Jiang, J. X. Xu, H. Q. Chu, Y. Xu, and Y. Zhang, "Evolution of $\mathrm{pH}$ and chemical composition of pore solution in carbonated concrete," Construction and Building Materials, vol. 28, no. 1, pp. 519-524, 2012.

[27] H. W. Whittington, J. McCarter, and M. C. Forde, "The conduction of electricity through concrete," Magazine of Concrete Research, vol. 33, no. 114, pp. 48-60, 1981.

[28] F. Hunkeler, "The resistivity of pore water solution-a decisive parameter of rebar corrosion and repair methods," Construction and Building Materials, vol. 10, no. 5, pp. 381-389, 1996.

[29] H. Xing, X. Yang, C. Xu, and G. B. Ye, "Strength characteristics and mechanisms of salt-rich soil-cement," Engineering Geology, vol. 103, no. 1-2, pp. 33-38, 2009. 
[30] W. Zhu, C. L. Zhang, and A. C. F. Chiu, "Soil-water transfer mechanism for solidified dredged materials," Journal of Geotechnical and Geoenvironmental Engineering, vol. 133, no. 5, pp. 588-598, 2007.

[31] C. Jaturapitakkul and R. Cheerarot, "Development of bottom ash as pozzolanic material," Journal of Materials in Civil Engineering, vol. 15, no. 1, pp. 48-53, 2003.

[32] M. Fall, M. Benzaazoua, and S. Ouellet, "Effect of tailings properties on paste backfill performance," in Proceedings of the 8th International Symposia on Mining with Backfill, pp. 193-202, Beijing, China, 2004.

[33] A. C. Raymond and C. H. Kenneth, "Mercury porosimetry of hardened cement pastes," Cement and Concrete Research, vol. 29, no. 6, pp. 933-943, 1999.

[34] K. Aligizaki, Pore Structure of Cement-Based Materials, Taylor \& Francis, New York, NY, USA, 2006.

[35] D. N. Winslow and S. Diamond, "A mercury porosimetry study of the evolution of porosity in Portland Cement," Journal of Materials, vol. 5, no. 3, 1970.

[36] E. J. Reardon, "Problems and approaches to the prediction of the chemical composition in cement/water systems," Waste Management, vol. 12, no. 2-3, pp. 221-239, 1992.

[37] M. Westerholm, B. Lagerblad, J. Silfwerbrand, and E. Forssberg, "Influence of fine aggregate characteristics on the rheological properties of mortars," Cement and Concrete Composites, vol. 30, no. 4, pp. 274-282, 2008.

[38] Ö. Özkan and I. Yüksel, "Studies on mortars containing waste bottle glass and industrial by-products," Construction and Building Materials, vol. 22, no. 6, pp. 1288-1298, 2008.

[39] A. M. Neville, Properties of Concrete, Addison Wesley Longman, Harlow, UK, 1997.

[40] P. Torkittikul and A. Chaipanich, "Utilization of ceramic waste as fine aggregate within Portland cement and fly ash concretes," Cement and Concrete Composites, vol. 32, no. 6, pp. 440-449, 2010.

[41] C. C. Yang, S. W. Cho, and L. C. Wang, "The relationship between pore structure and chloride diffusivity from ponding test in cement-based materials," Materials Chemistry and Physics, vol. 100, no. 2-3, pp. 203-210, 2006.

[42] D. A. Koleva, O. Copuroglu, K. van Breugel, G. Ye, and J. H. W. de Wit, "Electrical resistivity and microstructural properties of concrete materials in conditions of current flow," Cement and Concrete Composites, vol. 30, no. 8, pp. 731-744, 2008.

[43] K. A. Snyder, X. Feng, B. D. Keen, and T. O. Mason, "Estimating the electrical conductivity of cement paste pore solutions from $\mathrm{OH}^{-}, \mathrm{K}^{+}$and $\mathrm{Na}^{+}$concentrations," Cement and Concrete Research, vol. 33, no. 6, pp. 793-798, 2003.

[44] A. L. Horvath, Handbook of Aqueous Electrolyte Solutions, John Wiley \& Sons, New York, NY, USA, 1985.

[45] K. Wu, H. S. Shi, G. Shutter, G. Ye, X. L. Guo, and Y. Gao, "Effect of aggregate on chloride diffusivity of cement-based composite materials," Journal of the Chinese Ceramic Society, vol. 41, no. 11, pp. 1514-1520, 2013.

[46] D. N. Winslow, M. D. Cohen, D. P. Bentz, K. A. Snyder, and E. J. Garboczi, "Percolation and pore structure in mortars and concrete," Cement and Concrete Research, vol. 24, no. 1, pp. 2537, 1994 



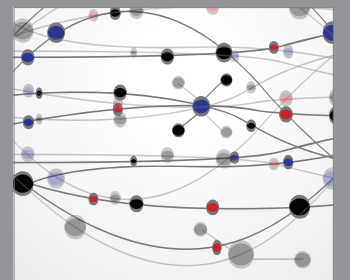

The Scientific World Journal
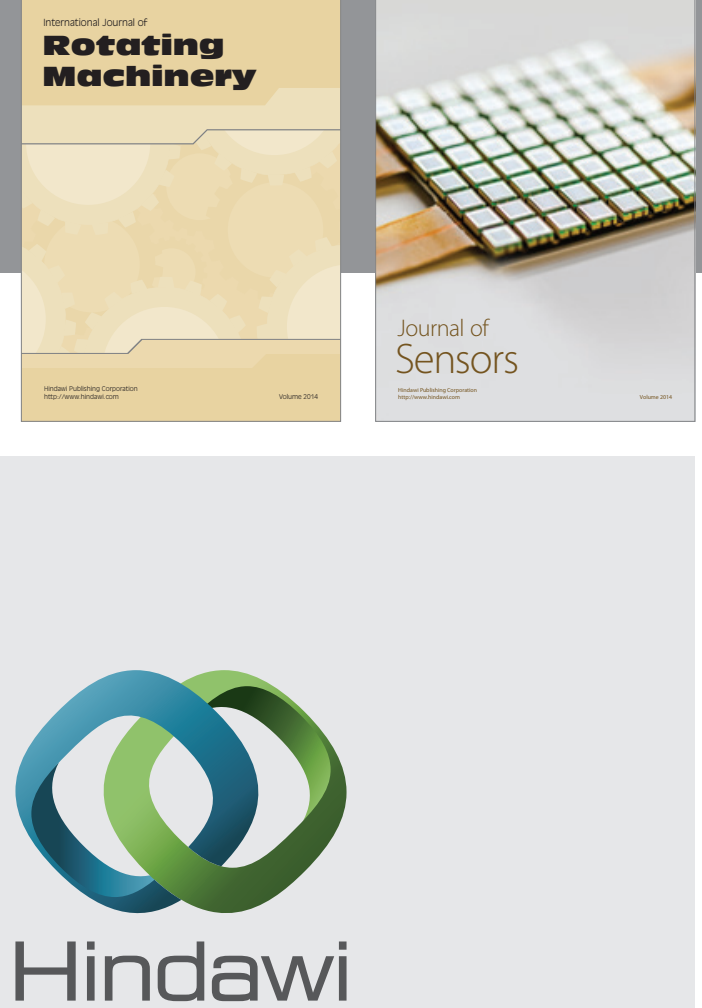

Submit your manuscripts at http://www.hindawi.com
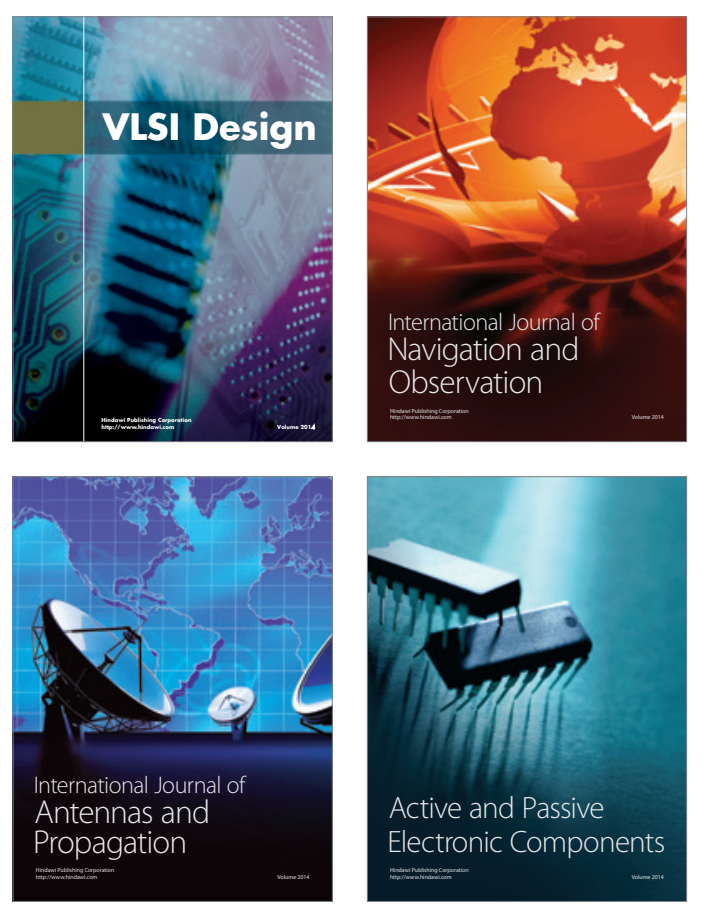
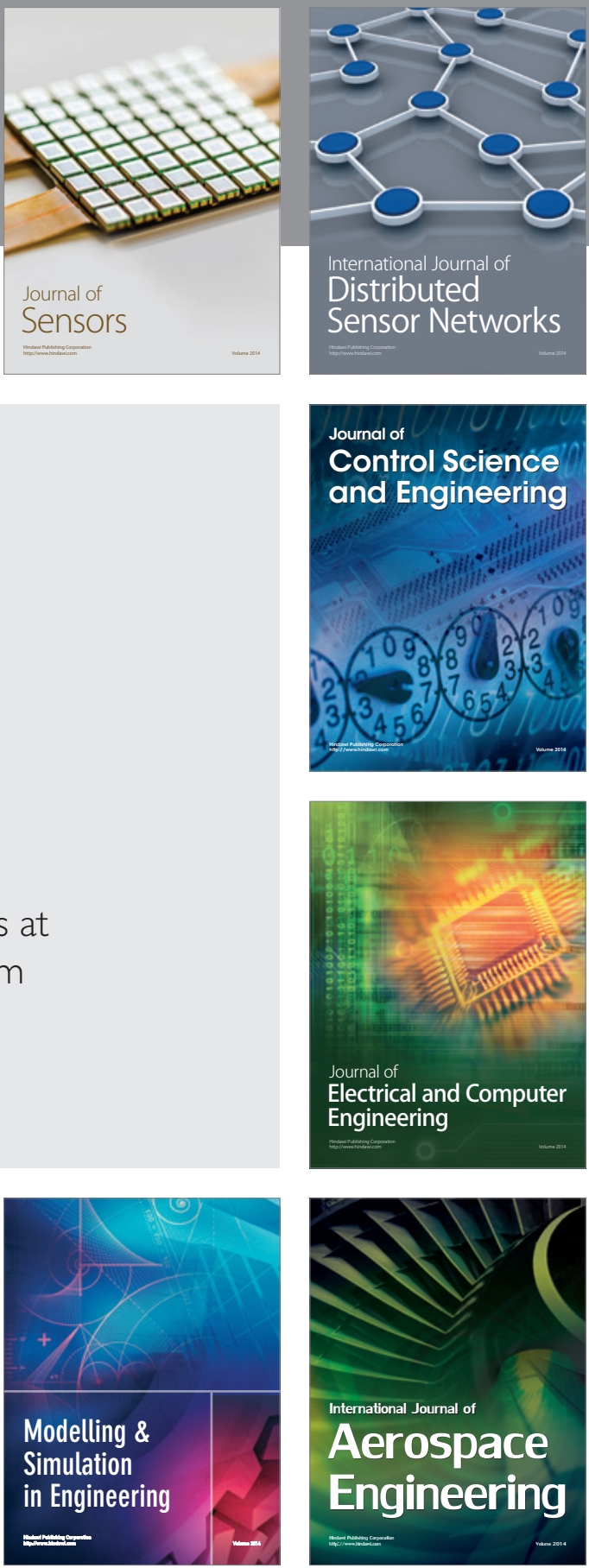

Journal of

Control Science

and Engineering
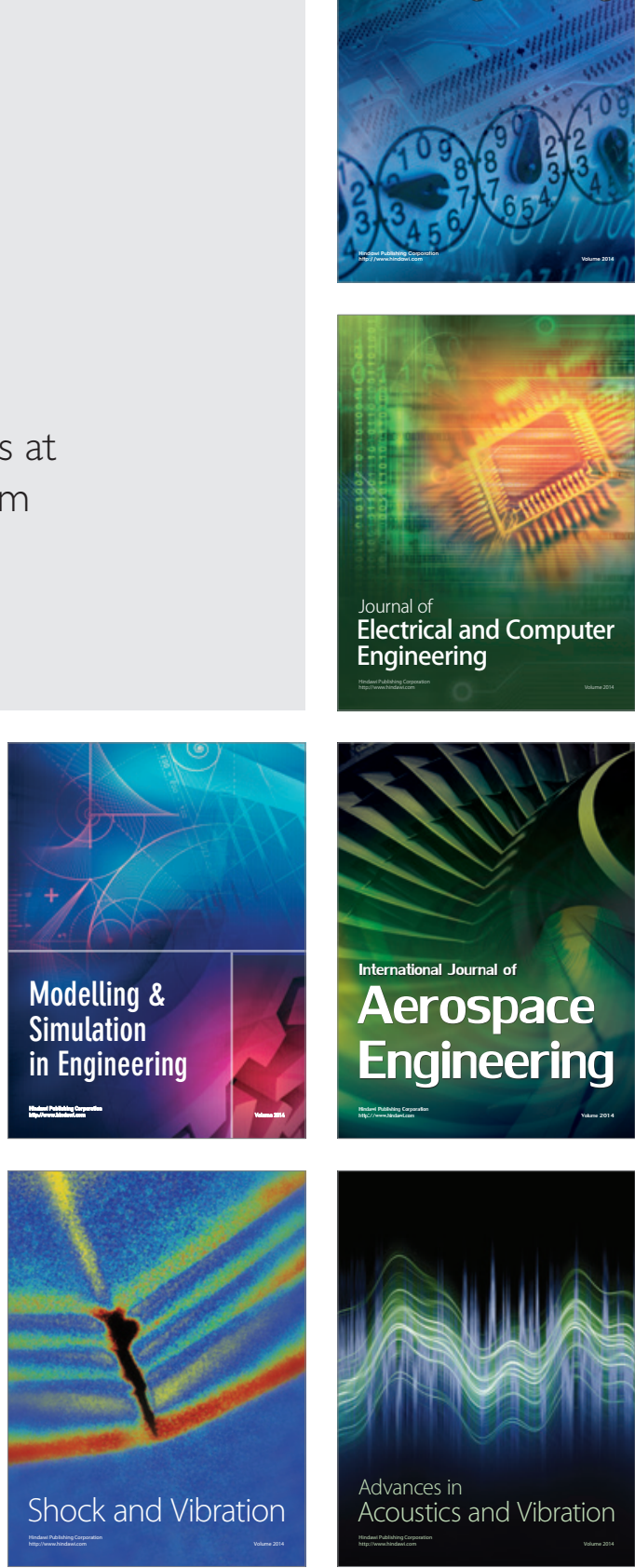